\title{
PENERAPAN SAK-EMKM PADA UMKM SCALE UP TANGERANG SELATAN MELALUI APLIKASI PENCATATAN INFORMASI KEUANGAN MIKRO DAN KECIL (SI APIK)
}

\author{
Tri Utami, Wiwit Irawati, Zulfa Rosharlianti, Dea Annisa, Dila Angraini \\ S1 Akuntansi, Fakultas Ekonomi, Universitas Pamulang \\ dosen00882@unpam.ac.id, wiwitira@unpam.ac.id ,dosen00876@unpam.ac.id \\ dosen00883@unpam.ac.id,dosen00879@unpam.ac.id
}

\begin{abstract}
Abstrak
Standar Akuntansi Keuangan Entitas Kecil, Mikro dan Menengah (SAK-EMKM) wajib diterapkan dalam pencatatan pembukuan para pelaku UMKM. Dalam ED SAK EMKM laporan keuangan dibuat sangat sederhana, laporan keuangan entitas disusun menggunakan asumsi dasar akrual dan kelangsungan usaha, sebagaimana yang digunakan oleh entitas selain entitas mikro, kecil, maupun menengah, serta menggunakan konsep entitas bisnis. Pengabdian kepada masyarakat (PKM) ini bekerjasama dengan Rumah Pemberdayaan Masyarakat (RPM) Institute Tangerang Selatan. Kegiatan PKM bertujuan untuk memperkenalkan SAK-EMKM dan mengaplikasikan SAK-EMKM pada laporan keuangan pelaku UKM dengan cara mudah dengan mengunakan aplikasi SI APIK . Khalayak sasaran PKM ini adalah para pelaku UKM wilayah Tangerang Selatan, yang tergabung dalam himpunan Rumah Pemberdayaan Masyarakat Institute. Metode yang digunakan dalam PKM ini adalah penyuluhan atau ceramah, tutorial, diskusi, pendampingan dan assessment. Hasil dari kegiatan PKM ini adalah dari sebanyak 100 peserta UKM, hanya 50 peserta UKM yang tepat dan disiplin dalam melakukan pembukuan menggunakan SI APIK, selama jangka waktu 3 bulan. Diharapkan PKM ini dapat bermanfaat untuk berbagai pihak di antaranya pelaku UKM itu sendiri, Bank Indonesia, Ikatan Akuntan Indonesia, Pemerintah dan bagi akademisi. Kata Kunci: SAK-EMKM, SI APIK, UMKM, RPM Institute.
\end{abstract}

\begin{abstract}
Financial Accounting Standards - Small, Micro and Medium Entity (SAK-EMKM) must be applied in the accounting records of UMKM actors. In the Exposure Draft SAK -EMKM the financial statements are made very simple, the entity's financial statements are prepared using the accrual basis and business going concern assumptions, as used by entities other than micro, small and medium entities, and using the concept of a business entity. This community service (PKM) is in collaboration with the Community Empowerment House (RPM) Institute of South Tangerang. Organizing PKM activities with the aim of introducing $S A K-E M K M$ and applying SAK-EMKM to the financial reports of UKM players in an easy way by using the SI APIK application. The target audience for this PKM is UKM players in the South Tangerang region, who are members of the Association of Community Empowerment Houses. The methods used in this PKM are counseling or lectures, tutorials, discussions, mentoring and assessments. The result of this PKM activity is that out of 100 UKM participants, only 50 UKM participants who are precise and disciplined in doing bookkeeping using SI APIK, for a period of 3 months. It is hoped that this PKM can be useful for various parties including SMEs themselves, Bank Indonesia, the Indonesian Accountants Association, the Government and academics.
\end{abstract}

Keywords: SAK-EMKM, SI APIK, UMKM, RPM Institute. 


\section{PENDAHULUAN}

Kota Tangerang Selatan, yang merupakan hasil dari pemekaran dari Kabupaten Tangerang adalah kota yang berbatasan langsung dengan DKI Jakarta yang telah mengalami kemajuan dan capaian di berbagai bidang dan peningkatan kesejahteraan ekonomi. Dalam bidang ekonomi, berdasarkan data BPS hingga tahun 2016, Perekonomian Tangerang Selatan menunjukkan hal positif di mana tingkat pendapatan perkapita dalam lima (5) tahun terakhir (2012-2016) selalu menunjukkan peningkatan (Budiyanto \& Effendy, 2020). Dinas Koperasi dan Usaha Kecil Menengah (UKM) Tangerang Selatan mencatat, sampai saat ini terdapat sekitar 26.700 UKM di Tangsel. Dinkop dan UKM akan terus memacu pelaku usaha kecil untuk berkembang dan bisa menghasilkan produk yang hebat. Tugas pemerintah adalah memfasilitasi guna mendorong pelaku UKM dapat berkembang (Republika, 2018).

Pesatnya perkembangan sektor UMKM di wilayah Tangerang Selatan tidak terlepas dari adanya permasalahan yang dialami. Salah satu permasalahan yang terjadi dan memang dirasakan langsung para pelaku UMKM ScaleUp Tangerang Selatan adalah kurangnya informasi mengenai cara pencatatan transaksi keuangan usaha yang baik, mudah, namun sesuai dengan standar keuangan yang berlaku. Para pelaku UMKM juga tidak menyadari bahwa sejak 1 Januari 2018, Standar Akuntansi Keuangan Entitas Kecil, Mikro dan Menengah (SAK-EMKM) wajib diterapkan dalam pencatatan pembukuan para pelaku UMKM, padahal dalam upaya mengukur kinerja keuangan suatu usaha dan untuk pengembangan bisnis perlu adanya laporan keuangan yang bankable (Ikatan Akuntansi Indonesia, 2016). Dalam ED SAK EMKM laporan keuangan dibuat sangat sederhana, laporan keuangan entitas disusun menggunakan asumsi dasar akrual dan kelangsungan usaha, sebagaimana yang digunakan oleh entitas selain entitas mikro, kecil, maupun menengah, serta menggunakan konsep entitas bisnis. Laporan keuangan entitas terdiri dari: (a) laporan posisi keuangan, (b) laporan laba rugi, dan (c) catatan atas laporan keuangan (SAK EMKM, 2016).

Tidak hanya kurangnya informasi mengenai SAK-EMKM, para pelaku UMKM ScaleUp juga kesulitan dalam mengelola keuangan, pada kenyataannya di lapangan, UMKM masih 'one man show' dalam menjalankan usahanya. Hal ini menyebabkan uang usaha tercampur dengan uang pribadi. Masalah ini hampir terjadi sekitar 90\% UMKM di Tangerang 
selatan. Perlu adanya metode baru untuk memisahkan pengelolaan uang tersebut. Metode "Dompet Traficlight" dapat menjadi solusi yang ditawarkan kepada para pelaku UMKM dalam mengelola keuangan yang masih dijalankan sendiri (Kompasiana, 2019). Mayoritas entitas Usaha Mikro, Kecil, dan Menengah (UMKM) di Indonesia sulit mendapatkan akses ke perbankan dan sumber pendanaan lainnya. Kondisi ini terjadi karena UMKM tidak memiliki laporan keuangan yang memadai dan sesuai standar yang berlaku di industri keuangan (Putra, 2018).

Masalah terakhir adalah bagaimana menerapkan SAK-EMKM dengan mudah, efisien waktu dan tenaga serta tidak perlu pemahaman teori yang berlebih. SI APIK (Sistem Informasi Aplikasi Pencatatan Informasi Keuangan) adalah sistem pencatatan keuangan secara online berbasis Android yang diluncurkan Bank Indonesia. Sistem tersebut akan mempermudah UMKM ScaleUp melakukan pencatatan laporan keuangan secara online. Salah satu keunggulan sistem ini adalah model penginputannya 'single enrty' sehingga tidak perlu pemahaman mengenai akuntansi, siapapun bisa melakukannya. SI APIK diharapkan memberi efek positif bagi aktifitas bisnis para pelaku usaha. Sebab mereka bisa membuat melalui ponsel android dengan mudah. Sistem aplikasi dapat digunakan oleh semua pengusaha UMKM dengan mengunduh program tersebut secara gratis melalui ponsel android di Google Playstore.

Standar Akuntansi keuangan atau SAK adalah pernyataan Standar Akuntansi Keuangan (PSAK) dan Interpretasi Standar Akuntansi Keuangan (ISAK) yang diterbitkan oleh Dewan Standar Ikatan Akuntan Indonesia (DSAK IAI) dan Dewan Standar Syariah Ikatan Akuntan Indonesia (DSAS IAI) serta peraturan regulator pasar modal untuk entitas yang berada di bawah pengawasannya. IAI selanjutnya menyusun SAK yang lebih sederhana dari SAK-ETAP yaitu SAK EMKM pada pertengahan 2015 menurut welojoe.id. Hal ini dikarenakan masih banyaknya UMKM di Indonesia yang belum mampu untuk membuat serta menyusun laporan keuangan yang sesuai dengan SAK yang berlaku (Ikatan Akuntan Indonesia, 2016).

Sesuai dengan definisi dari SAK EMKM, pengertian serta kriteria EMKM berdasarkan peraturan perundang-undangan yang berlaku di Indonesia, setidaktidaknya selama dua tahun berturut-turut. Berikut definisi UMKM yang telah ditetapkan oleh 
Undang-undang No. 20 tahun 2008. (1) Usaha Mikro adalah usaha produktif milik orang perorangan dan/atau badan usaha perorangan yang memiliki kekayaan bersih maksimal 50 juta rupiah dan hasil penjualan tahunan dengan maksimal 300 juta rupiah. (2) Usaha Kecil adalah usaha ekonomi produktif yang berdiri sendiri, yang dilakukan oleh orang perorangan atau badan usaha yang bukan merupakan anak perusahaan atau bukan cabang perusahaan yang dimiliki, dikuasai, atau menjadi bagian baik langsung maupun tidak langsung dari Usaha Menengah atau Usaha Besar yang memiliki kekayaan bersih maksimal 50 juta rupiah dan hasil penjualan tahunan dengan maksimal 500 juta rupiah. (3) Usaha Menengah adalah usaha ekonomi produktif yang berdiri sendiri, yang dilakukan oleh orang perorangan atau badan usaha yang bukan merupakan anak perusahaan atau cabang perusahaan yang dimiliki, dikuasai, atau menjadi bagian baik langsung maupun tidak langsung dengan Usaha Kecil atau Usaha Besar dengan jumlah kekayaan bersih maksimal 300 juta rupiah dan hasil penjualan tahunan dengan maksimal 2 miliar rupiah.

Sejak berlakunya SAK-EMKM Januari 2018, pelaku UMKM dituntut untuk dapat menyajikan laporan keuangan sesuai standar akuntansi yang berlaku. Rumitnya pemahaman mengenai siklus akuntansi, membuat pelaku UKM tidak disiplin dalam melakukan pencatatan transaksi keuangan. Belajar ilmu akuntansi memang tidak dapat dipahami secara langsung, namun harus bertahap sesuai prosedur akuntansi. Untuk mencapai itu semua tentu tidak sedikit orang yang mengalami kesulitan mempelajarinya yang disebabakan beberapa faktor tertentu. Karena pada dasarnya kemampuan yang dimiliki oleh seseorang berbeda-beda. Jadi, bila mengalami kesulitan hal tersebut hanya akan menyebabkan mereka lebih lambat di beberapa hal. (Setianingsih \& dkk, 2019)

Dengan adanya model digitalisasi recording untuk akuntansi di banyak aplikasi di marketplace atau appstore dapat membantu pelaku UMKM lebih termotivasi untuk terus melakukan pembukuan, namun dari semua aplikasi akuntansi untuk UKM hanya SI APIK yang sesuai dengan SAK-EMKM. Salah satu kesesuaiannya adalah bentuk penyajian laporan keuangannya.

1. Laporan Keuangan Akurat

Salah satu keakuratan SI APIK dalam menyajikan laporan keuangan 
adala data yang disajikan dalam laporan keuangan diambil dari transaksi yang menggunakan satuan barang. Untuk transaksi penjualan sektor usaha perdagangan, transaksi tidak akan dapat dilakukan jika tidak melakukan transaksi pembelian barang atau jika tidak melakukan setting saldo persediaan barang di awal periode. Artinya jika hanya diukur dengan satuan rupiah, pengguna dapat melakukan transaksi penjualan tanpa melakukan transaksi pembelian barang atau melakukan setting saldo persediaan barang di awal periode.

Hal tersebut menyebabkan laba yang tersaji dalam laporan laba rugi semu. Karena selisih antara harga pokok penjualan dengan harga jual barang tidak dapat terukur dengan jelas. Selain itu, adanya menu stokopname pada tiap sektor usaha, menjadikan SIAPIK lebih akurat dibandingkan dengan aplikasi sejenis.

\section{Keamanan Data}

SI APIK meminta password dan konfirmasi password saat registasi akun, tujuannya tidak lain untuk melindungi data dari pihak yang memiliki kepentingan tidak baik. Setiap akan login akun usaha tersebut, SI APIK juga selalu meminta memasukan password untuk memastikan bahwa yang akan mengakses data tersebut adalah benar pengguna yang tepat.

3. Dapat Dilakukan Tanpa Pengetahuan Dasar Akuntansi Aplikasi rakitan bank Indonesia tersebut didesain untuk pelaku UKM yang memang mayoritas bukan seorang akunting, namun dituntut untuk dapat membuat laporan keuangan.

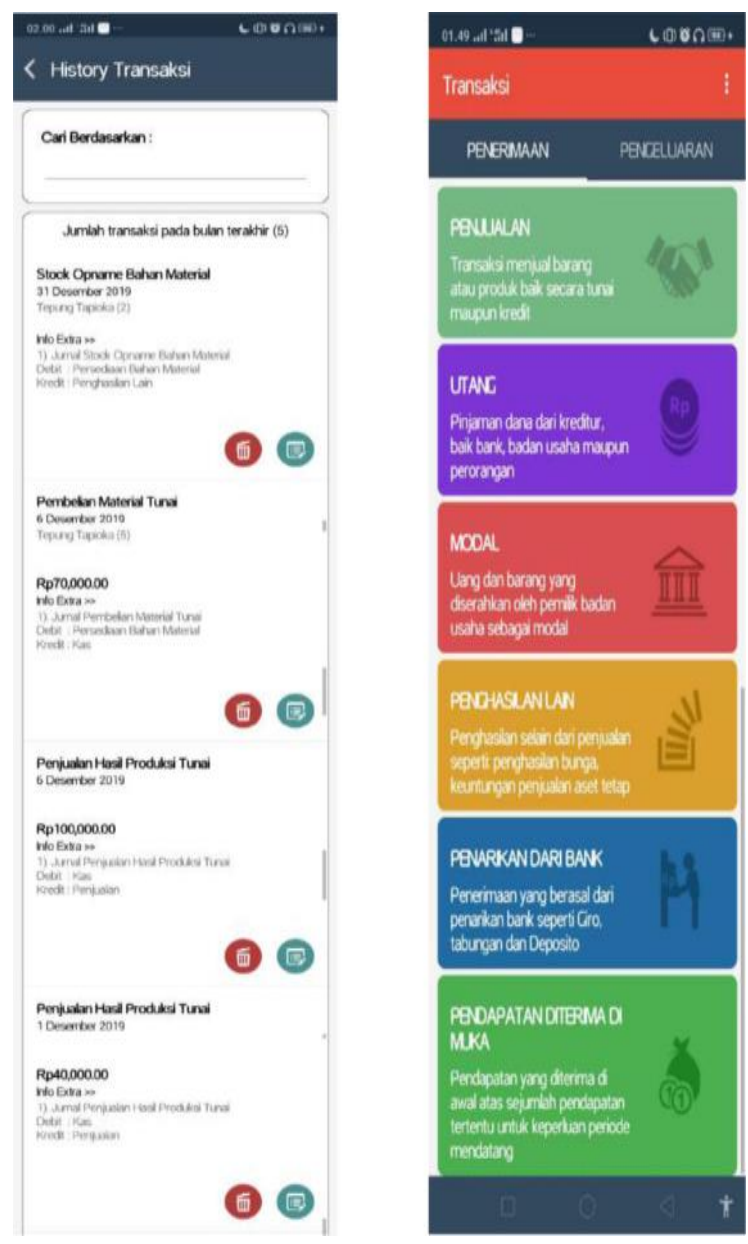

SI APIK menggunakan model single entry namun transaksi yang dihasilkan mewakili double entry. 
Pengguna hanya perlu menganalisa transaksi yang sedang berlangsung adalah kategori penerimaan atau pengeluaran uang. Berikut tampilan SI APIK:

\section{Gambar 1. Tampilan Aplikasi SI APIK Melalui Ponsel}

\section{METODE}

Pengabdian kepada masyarakat dapat diartikan sebagai respon akademik masyarakat kampus atas kebutuhan, tantangan, atau persoalan yang dihadapi oleh masyarakat, baik secara langsung maupun tidak langsung (Hidayati dkk, 2019)

Khalayak sasaran Pengabdian Kepada Masyarakat kali ini adalah para pelaku UMKM di wilayah Tangerang selatan yang tergabung dalam himpunan Rumah Pemberdayaan Masyarakat Institute (RPM Institute) yang dipimpin oleh Bapak Husain sebanyak 100 pelaku usaha sehingga perkembangannya dapat diketahui dan dipantau dengan mudah. Lebih jauh dari itu, harapannya peserta pelatihan dapat menularkan ilmu yang didapatkan kepada pelaku UMKM lain yang berada di sekitarnya.

Kegiatan pendampingan dan konsultasi dilakukan di kampus Universitas Pamulang, Jl. Surya Kencana No. 1, Pamulang, Kota
Tangerang Selatan. Waktu penyuluhan dilakukan di tanggal 24 - 25 Februari 2020 hari senin dan selasa sesi I pukul 08:00 - 12:00 WIB dan sesi II pukul 13:00 - 17:00 WIB. Pendampingan dan konsultasi dilakukan pada hari senin jumat pukul 15:00 dan 20:00 - 23:00 atau di jam yang telah disepakati.

Pelaksanaan kegiatan Pengabdian Pada Masyarakat ini dilakukan dengan menggunakan metode ceramah, tutorial, diskusi, pendampingan dan konsultasi, dan assesment. Adapun sistematika pelaksanaan kegiatan pengabdian ini adalah sebagai berikut:

1. Langkah 1 (Metode Ceramah): Peserta diberikan motivasi agar memiliki kemauan untuk menggunakan akuntansi dalam kegiatan bisnisnya. Selain itu, peserta diberikan materi gambaran umum tentang akuntansi UMKM dan peran penting akuntansi bagi UMKM.

2. Langkah 2 (Metode Tutorial): Peserta pelatihan diberikan materi akuntansi mulai dari pencatatan sampai dengan menyusun laporan keuangan dengan SI APIK. Langkah kedua diselenggarakan selama 2 hari, masing-masing 1 jam per hari terbagi dalam dalam 2 sesi, sesi pertama pukul 08:00 - 12:00 dan sesi kedua pukul 13:00 - 17:00. 
3. Langkah 3 (Metode Diskusi): Peserta pelatihan diberikan kesempatan untuk mendiskusikan permasalahan yang berkaitan dengan keuangan UMKM yang selama ini dihadapi. Langkah ketiga diselenggarakan selama 1 jam.

4. Langkah 4 (pendampingan dan konsultasi): peserta diberi kesempatan untuk didampingi selama 3 bulan dalam menyusun laporan keuangan. Peserta diberi kesempatan untuk bertemu dengan para mentor di waktu dan tempat yang telah disepakati.

5. Langkah 5 (Evaluasi/ Assesment) : tahap pertama evaluasi, peserta diuji dengan diberi batas waktu apakah mengumpulkan laporan keuangan perusahaannya yang telah diajarkan. Evaluasi tahap kedua, peserta diuji apakah laporan yang disajikan benar atau salah.

\section{HASIL DAN PEMBAHASAN}

Kegiatan pelatihan akuntansi UMKM bagi UMKM untuk meningkatkan bonafiditas dan kedisplinan pelaku UKM, dilaksanakan selama 5 tahap dalam beberapa hari. Pelaksanaan pelatihan dibagi dalam 3 tahap selama 2 hari. Pada hari Senin 24 Februari 2020 dari pukul 08.00 sampai dengan 12.00. Acara pertama diawali dengan registrasi peserta sekaligus mengisi Tanya jawab seputar keuangan umum usaha peserta. Selanjutnya, dilanjutkan dengan pemberian materi pertam dengan topik materi pengenalan SAK-EMKM dan seputar akuntansi UMKM. Materi ini membahas pentingnya akuntansi bagi

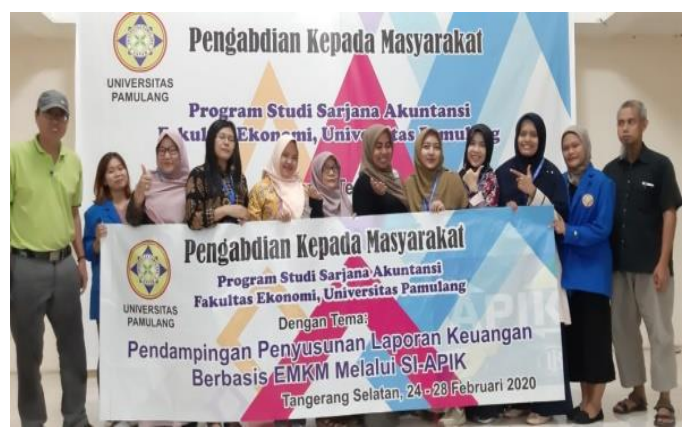

UMKM. Materi pertama ini diakhiri pada pukul 09.30.

\section{Gambar 2. Peserta PKM dan Narasumber Sebelum Sesi Penyuluhan}

Materi kedua yaitu pelatihan akuntansi sederhana menggunakan SI APIK. Materi yang dipilih adalah UKM dengan jenis usaha dagang, materi berlangsung selama 4 jam. Dari pukul 09.30 - 12.30. Peserta sebelumnya sudah diberitahu untuk menginstall aplikasi SI APIK pada gawainya. Jumlah peserta sesi pertama adalah 25 orang. Sesi kedua dimulai pada pukul 13.00 dan berakhir pada 17.00. Sesi kedua ini model pembelajarannya juga sama dengan sesi I, materi juga disampaikan oleh Ibu Ratih Qadarti Anjilni, SE., M.Ak. dan dibantu Ibu Asih Handayani, SE.,M.Ak. dengan 
topik transaksi transaksi akuntansi UMKM dan pelaporan akuntansi UMKM. Pelatihan sesi kedua dilaksanakan pada hari yang sama.

Pelatihan pada tanggal 25 Februari 2020 diawali pukul 08.00 sampai dengan pukul 12.30. Selanjutnya pada pukul 12.30 sampai dengan 17.00 dengan peserta yang berbeda di tiap sesi dan di kedua hari tersebut. Selanjutnya pendampingan untuk menggunakan SI APIK yang disesuaikan dengan usaha peserta masing-masing dilakukan pada hari kerja dan hari libur pada jam dan tempat yang telah disepakati. Pendampingan dilakukan selama 3 bulan sampai bulan Mei 2020, pendampingan dilakukan untuk persiapan assessment.

Setelah materi pertama dilanjutkan dengan materi kedua mengenai transaksitransaksi akuntansi UMKM yang diinput menggunakan SI APIK. Pada sesi ini, pemateri memberikan materi tentang apa itu SI APIK dan cara menggunakan SI APIK masing-masing audiens diminta sudah terinstall aplikasi SI APIK sebelumnya. Kemudian bersama-sama peserta diminta menganalisa contoh transaksi dari pemateri kemudian menginputnya menggunakan SI APIK. Langkah-langkah dan maksud dari tiap transaksi dijelaskan oleh pemateri.

Pelatihan hari kedua dilaksanakan pada hari Selasa 25 Februari 2020. Sama dengan pelatihan pada tanggal 24 Februari 2020, pelatihan pada tanggal 25 Februari 2020 diawali pukul 08.00 sampai dengan pukul 17.00 dengan pola pembelajaran yang sama dan dengan pemateri yang sama pula. Peserta pengabdi yang lain menjadi instruksi pendamping ketika peserta menginput transaksi pada SI APIK. Selanjutnya pendampingan untuk menggunakan SI APIK yang disesuaikan dengan usaha peserta masing-masing dilakukan pada hari kerja dan hari libur pada jam dan tempat yang telah disepakati. Pendampingan dilakukan selama 3 bulan sampai bulan Mei 2020, pendampingan dilakukan untuk persiapan assessment.

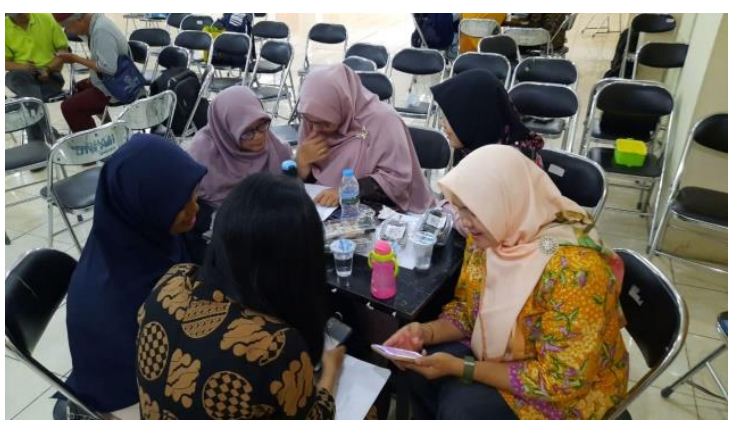

Gambar 3. Peserta Antusias Menggunakan Aplikasi SI APIK

Assesment dilakukan selama 2 (dua) kali, Assesment pertama pada tanggal 30 Maret 2020, dengan peserta yang lulus sejumlah 87 peserta dari 100 peserta. Assessment kedua dilakukan pada tanggal 05 Mei 2020 dengan peserta yang lulus sejumlah 50 orang.

\section{KESIMPULAN}


Kegiatan pelatihan akuntansi UMKM bagi usaha mikro, kecil, menengah (UMKM) untuk meningktakan bonafiditas perusahaan berjalan dengan lancar. Sekaligus meningkatkan kedisplinan pelaku UMKM terhadap pencatatan akuntansi. Semua peserta antusias mengikuti acara hingga selesai dan merasakan manfaat pelatihan bagi kemajuan usaha mereka.

\section{REFERENSI}

Budiyanto, A., \& Effendy, A. A. (2020). Analisis Kebijakan Pemerintah Kota Tangerang Selatan Dalam Memberdayakan Peranan UMKM dan Koperasi Terhadap Perekonomian Kota Tangerang Selatan. Jurnal Mandiri, 4(1), 80-93.

Hidayati, Wahyu Nurul dkk. (2019) Sosialisasi teman bisnis catatan keuangan. Jurnal ABDIMISI Universitas Pamulang, 1(1), 41-46.

Ikatan Akuntan Indonesia. (2016). Standar Akuntansi Keuangan- IAI Global. In IAI Global.
Ikatan Akuntansi Indonesia, I. (2016). Standar Akuntansi Keuangan Entitas Mikro, Kecil, dan Menengah. Sak EMKM.

Putra, Y. M. (2018). Pemetaan Penerapan Standar Akuntansi Keuangan Emkm Pada Umkm Di Kota Tangerang Selatan. Jurnal Profita. https://doi.org/10.22441/profita.2018. v11.02.004

Setianingsih, \& dkk. (2019). Pengaruh Kemampuan Bersaing di Dunia Kerja dengan Pelatihan Software Zahir Accounting. Tangerang Selatan: Jurnal ABDIMISI.

SAK EMKM. (2016). Standar Akuntansi Keuangan Entitas Mikro, Kecil, dan Menengah. SAK EMKM.

https://goukm.id/sak-emkm/ diakses pada tanggal 06 januari 2020. Pukul 00:54

https://www.respublika.id/2018/11/24/pert umbuhan-ukm-kota-tangsel-

menjanjikan/diakses 18 Agustus 2020

https://www.kompasiana.com/ratihanjilni/ 5efcc56ed541df10c929cca2/si-apik solusi-disiplin-akuntansi-untuk umkm-pengabdian-kepadamasyarakat-dosen-universitaspamulang-jilid-ii?page $=2$ diakses 17 Agustus 2020 